\title{
Potential for transmission of Stenocarpella macrospora from inoculated seeds to maize plants grown under controlled conditions ${ }^{1}$
}

\author{
Carolina da Silva Siqueira ${ }^{2 *}$, José da Cruz Machado², Ellen Noly Barrocas ${ }^{3}$, \\ Mirella Figueiró de Almeida ${ }^{2}$
}

\begin{abstract}
Maize seeds infected by Stenocarpella macrospora can cause stalk and ear rot and leaf spot. Transmission of this pathogen through seeds may vary according to the cultivar, climatic conditions, and virulence of the pathogen among other factors. The aim of this study was to assess the transmission rate of $S$. macrospora from seeds of the maize cultivars $\mathrm{C} 1-$ RB9308YG and C2-RB9108 using artificially infected seeds grown under two temperatures $\left(20^{\circ} \mathrm{C}\right.$ and $\left.25^{\circ} \mathrm{C}\right)$. Seeds were inoculated by the osmotic conditioning method for $24 \mathrm{~h}$ (inoculum potential - P1), $48 \mathrm{~h}$ (P2), $72 \mathrm{~h}$ (P3) and $96 \mathrm{~h}$ (P4). After inoculation, 25 seeds were distributed individually in plastic cups with substrate, with 4 replicates per treatment. At the end of twenty-eight days of daily assessments, all plants were analyzed for the presence of the pathogen by biological methods, and some were sampled at random and analyzed Bio-PCR. The maximum percentages of dead seeds/seedlings in pre-emergence were $74.5 \%$ and $82.5 \%$ for $\mathrm{P} 3$ and $\mathrm{P} 4$, respectively. The highest total rate of transmission of the pathogen under study was $85.8 \%$ for seeds of the cultivar $\mathrm{C} 1$ at the highest inoculum potential (P4), grown at the temperature of $20^{\circ} \mathrm{C}$.
\end{abstract}

Index terms: seed pathology, inoculum potential, ear and stalk rot, fungus.

\section{Potencial de transmissão de Stenocarpella macrospora de sementes inoculadas para plantas de milho cultivadas em condições controladas}

\begin{abstract}
RESUMO - Sementes de milho infectadas por Stenocarpella macrospora podem ocasionar podridão do colmo e da espiga e manchas foliares. A transmissão deste patógeno por meio de sementes pode variar de acordo com a cultivar, as condições climáticas e a virulência do patógeno, entre outros fatores. O objetivo foi avaliar a taxa de transmissão de $S$. macrospora a partir de sementes das cultivares de milho C1-RB9308YG e C2-RB9108, infectadas artificialmente e cultivadas sob duas temperaturas $\left(20^{\circ} \mathrm{C}\right.$ e $\left.25{ }^{\circ} \mathrm{C}\right)$. A inoculação das sementes foi realizada pelo método de condicionamento osmótico, por 24 (potencial de inóculo - P1), 48 (P2), 72 (P3) e 96 (P4) horas. Após a inoculação, 25 sementes foram distribuídas, individualmente, em copos plásticos contendo substrato, com 4 repetições por tratamento. Ao final de 28 dias de avaliações diárias, todas as plantas foram analisadas para a presença do patógeno por métodos biológicos e algumas, amostradas ao acaso, por Bio-PCR. As porcentagens máximas de morte em pré-emergência de sementes/plântulas foram de 74,5\% e 82,5\%, para P3 e P4, respectivamente. A maior taxa de transmissão total do referido patógeno neste estudo foi de $85,8 \%$, ocorrida no potencial de inóculo mais elevado (P4) em sementes da cultivar $\mathrm{C} 1$, cultivadas na temperatura de $20^{\circ} \mathrm{C}$.
\end{abstract}

Termos para indexação: patologia de sementes, potencial de inóculo, podridão do colmo e da espiga, fungo.

\section{Introduction}

Stenocarpella macrospora (Earle) Sutton, causal agent of stalk and ear rot and leaf spots in maize has been increasing in various maize producing regions in Brazil. Currently, it is quite often detected in seeds, a situation attributed to the increase in the occurrence and intensity of the disease in the fields (Casa et al., 2006; Mário et al., 2011).

${ }^{1}$ Submitted on 10/07/2013. Accepted for publication on 03/25/2014.

${ }^{2}$ Departamento de Fitopatologia, Universidade Federal de Lavras - UFLA, Caixa Postal 3037, 37200-000, Lavras, MG, Brasil.
The fungus $S$. macrospora is necrotrophic, exhibiting a parasitic phase in the developing plant and saprophytic phase in crop residue. Thus, the pathogen may be found surviving outside the crop season as mycelium inside the seeds, forming pycnidia in the crop residues on the soil surface (Casa et al., 2003). Therefore, infected seeds constitute potential mean of dissemination of the pathogen in growing areas and in areas where the maize has not yet been grown. In addition, the maize grain infected

${ }^{3}$ Department of Plant and Environmental Sciences, 2360, Taastrup, Denmark. "Corresponding author $<$ kerolpet@gmail.com> 
by the fungus (injured kernels) is unsuitable for consumption and for formulating feeds since they may have the toxin diplodiol (Petatán-Sagahón et al., 2011).

The transmission process of $S$. macrospora from the seed to the plant occurs through the mesocotyle, reaching the crown, the roots, and, finally, the base of the stalk. It is a slow process and may be found in different phases of the crop, from the beginning to the end (Casa et al., 2006). The association of the pathogen with seeds ensures direct access of the parasite to the nutrition source at the time of seed germination and seedling emergence. Due to diverse physical and biological factors, in addition to the position of the pathogen within the seed and its intensity, the pattern of transmission through seeds becomes quite variable.

Quantification of the transmission rate of S. macrospora in maize has not yet been undertaken and according to Casa et al. (2006), it is a difficult task through the fact of this fungus being linked to lack of seed germination, to asymptomatic plants, and to the presence of other fungi associated with the seed, which may interfere in this quantification since a selective medium for the pathogen is not available.

The aim of this study was to understand and to assess the transmission rate of $S$. macrospora in maize seeds, considering the interference of aspects like the inoculum potential of the pathogen, the environment temperature, and genotypes under controlled growing conditions.

\section{Materials and Methods}

Obtaining and multiplying fungal isolates and health testing of the seeds used: two isolates of S. macrospora, CMLAPS375 and CMLAPS10, from the mycological collection of the Seed Pathology Laboratory of Federal University of Lavras (Lavras, Minas Gerais, Brazil) were used. The isolates were multiplied in Petri dishes containing the PDA culture medium ( $20 \mathrm{~g}$ of agar, $20 \mathrm{~g}$ of dextrose, and $200 \mathrm{~g}$ of potato/L) and placed in a BOD chamber at a temperature of $25 \pm 2{ }^{\circ} \mathrm{C}$ and 12 hours phototperiod. The cultivars used, RB9308YG (cultivar susceptible to $S$. macrospora - C1) and RB9108 (cultivar moderately resistant to S. macrospora-C2), were provided by the Riber Seeds company, located in Patos de Minas, MG. The health and physiological testing of the maize seeds were determined according to the Rules for Seed Testing (Brasil, 2009a) and the Seed Health Analysis Manual (Brasil, 2009b). From those analysis, it was observed that the seed lots used in this study were not carriers of $S$. macrospora. For the cultivar C1 (RB9308YG), incidences of $28.5 \%$ of Fusarium verticillioides and $13 \%$ of Penicillium sp. were detected, and, for $\mathrm{C} 2$ (RB9108), an incidence of $25.5 \%$ and $11 \%$, for the respective fungi were observed in $\mathrm{C} 1$. Germinations of these lots were $98 \%$ normal seedlings for $\mathrm{C} 1$ and $96 \%$ for $\mathrm{C} 2$.

Seed preparation and inoculation: inoculation of the seeds was carried out by the osmotic conditioning method (Machado et al., 2012) through which the seeds were kept in contact with colonies of the fungal isolates for different exposure times. First, the isolates were cultivated on PDA culture medium in Petri dishes containing mannitol solute with water potential of $-1.4 \mathrm{MPa}$, adjusted by the software SPPM (Michel and Radcliffe, 1995). The seeds of both cultivars were disinfested with $1 \%$ sodium hypochlorite for 1 minute, washed three times with distilled water, and dried in laboratory conditions. After that, the seeds were evenly distributed over the fungal colonies five days old, for periods of 24, 48, 72 and 96 hours, these times corresponding to the different inoculum potentials of P1, P2, P3 and P4, respectively. Incubation occurred in a BOD chamber with temperature of $25 \pm 2{ }^{\circ} \mathrm{C}$ and 12 -h photoperiod. For the control treatments, the same periods as mentioned for inoculation were also used, in which seeds of both cultivars were placed in Petri dishes containing only the PDA medium with the addition of mannitol for assessment of the possible effect of water restriction on the physiological quality of the maize seeds.

Seed health testing: to obtain the percentage of incidence of S. macrospora in inoculated seeds, blotter test were performed to estimate the transmission rate of the fungus from the seeds to the plants in the different inoculum potentials. Thus, the inoculated maize seeds were distributed on a paper substrate soaked with the OA medium ( $20 \mathrm{~g}$ of agar and $30 \mathrm{~g}$ of oatmeal/L), a medium favorable to the formation of pycnidia of the species (Silva and Juliatti, 2005), in 15-cm diameter Petri dishes, with eight replications of 25 seeds per dish. The seeds were then placed in a freezer at $-20{ }^{\circ} \mathrm{C}$ for 24 hours and then incubated for 7-15 days in a growing chamber with a temperature of $20 \pm 2{ }^{\circ} \mathrm{C}$ and $12-\mathrm{h}$ photoperiod. At the end of this period, the seeds were examined individually through a stereoscopic microscope, checking for the incidence of the $S$. macrospora.

Assessments for determination of the transmission rate: the seeds were distributed in $200 \mathrm{~mL}$ plastic cups containing a commercial substrate (Multiplanta trop sc $25 \mathrm{~kg}$ ), sowing one per cup and a total of 100 cups equally distributed in four trays (replications). The experiment was conducted in chambers with temperatures adjusted to $20{ }^{\circ} \mathrm{C}$ and $25 \pm 2{ }^{\circ} \mathrm{C}$ and a 12 light-hour photoperiod (daylight NSK T10 40 W 6500 K FL40T10-6 $60 \mathrm{~Hz}$ )/12 hours of darkness. The emergence of plants which were symptomatic and asymptomatic of the disease in focus was assessed daily. Fragments of symptomatic plants were aseptically placed and incubated in Petri dishes containing the PDA medium for confirmation of the presence of $S$. macrospora in the tissues assessed. Twenty-eight days 
after sowing, all the asymptomatic plants were collected and $2 \mathrm{~cm}$ fragments at the height of the root collar (C) and last leaf insertion (LI) were disinfested in $70 \%$ alcohol, $1 \%$ sodium hypochlorite, and distilled and sterilized water for 1 minute and dried on sterilized paper. All the fragments were deposited on Petri dishes containing the PDA medium and incubated at the temperature of $25{ }^{\circ} \mathrm{C}$ and 12 -h photoperiod. After 7 and 15 days, the fragments were individually assessed in a stereoscopic microscope for observation of structures characteristic of S. macrospora (Mario and Reis, 2001). Detection of $S$. macrospora in at least one of the fragments examined per plant was sufficient for confirmation of the transmission of such pathogen from the seed to the plant. A randomized block experimental design was used in a triple factorial arrangement of $2 \times 2 \times 4$ ( 2 temperatures, 2 cultivars, and 4 inoculum potentials), with four replications per treatment. Determination of the total transmission rate (T.T.) of $S$. macrospora from the seeds to the plants for each type of exposure time was calculated based on the formula (Teixeira and Machado, 2003):

$$
\text { T.T. }(\%)=[\text { I.R. }(\%) / \text { I.S. }(\%)] * 100
$$

in which:

I.R.(\%) = infection rate of S. macrospora in seeds in preemergence up to fragments (C and LI) of maize plants at 28 days of age;

I.S. $(\%)=$ incidence of $S$. macrospora in inoculated seeds, based on the seed health testing.

Confirmation of the presence of S. macrospora in asymptomatic plants by the molecular technique: at least $20 \%$ of the plants of each treatment in which disease symptoms were not observed were collected at random and subjected to analysis in Bio-PCR. For that purpose, 2-cm fragments from the region of the root collar (C) and from the last leaf insertion (LI) of the plants were assessed individually. The Wizard $^{\circledR}$ Genomic DNA Purification Kit (Promega, Madison, WI) was used for DNA extractions, according to the protocol recommended by the manufacturer. The primers P1/P2 described by Xia and Achar (2001), specific for the genus Stenocarpella, were used to detect the presence of the fungus in the tissues (Barrocas et al., 2012). Amplification was performed in $25 \mu \mathrm{L}$ of the reaction containing the PCR buffer (IB buffer - Phoneutria, Brazil - $500 \mathrm{mM} \mathrm{KCl,} 100$ $\mathrm{mM}$ Tris- $\mathrm{HCl} \mathrm{pH} 8.4,1 \%$ Triton X-100, $\mathrm{MgCl} 2$ ), dNTPs (2.5 mM of each dNTP), primers $(10 \mu \mathrm{M}$ of each forward or reverse primer), and $5 \mathrm{U} / \mu \mathrm{L}$ of Taq DNA polymerase (Phoneutria, Brazil), with the addition of $2 \mu \mathrm{L}$ of the DNA to make up the total volume. The cycle initially consisted of
$95{ }^{\circ} \mathrm{C}$ for 3 minutes, denaturation at $94{ }^{\circ} \mathrm{C}$ for 30 seconds, annealing at $60{ }^{\circ} \mathrm{C}$ for 1 minute, and extension of $72{ }^{\circ} \mathrm{C}$ for 1 minute, with final extension of $72{ }^{\circ} \mathrm{C}$ for 10 minutes, for a total of 30 cycles. An aliquot of $10 \mu \mathrm{L}$ was used to analyze the PCR products in 1\% agarose gel in TBE buffer, stained with GelRed ${ }^{\circledR}$ at $150 \mathrm{~V}$ for approximately 2 hours. The PCR products were observed in a UV transilluminator, L-Pix HE equipment (Loccus Biotecnologia, Brasil).

Statistical analysis: statistical analyses were carried out with the assistance of the Sisvar ${ }^{\circledR}$ program, version 5.3 (Ferreira, 2011). Analyses of variance were carried out individually for each isolate of Stenocarpella macrospora, in addition to the control (not inoculated), in the triple factorial arrangement. For the death in pre-emergence and transmission rate variables with observation of symptomatic and asymptomatic plants, the analyses of variance were corrected through transformation of the data in square root (data +1$)$. The mean values among the treatments were compared by regression, the Tukey test, or Student $t$ test $(\mathrm{P} \leq 0.05)$. For the total transmission rate, all the percentages of the transmission rates of symptomatic and asymptomatic plants and death in pre-emergence were considered.

\section{Results and Discussion}

Analysis of variance for death in pre-emergence and transmission rates of Stenocarpella macrospora from seeds to plants exhibited a triple non-significant interaction $(p \leq 0.05)$ when the seeds were inoculated with the two isolates of the pathogen.

The presence of the pathogen was not detected in the plants of the control treatment. Therefore, the seeds of these treatments responded only to the possible interference of water restriction from mannitol in their physiological quality, and these results were used for estimation of the percentage of death in pre-emergence caused by the pathogen. The same is undertaken in different studies of the fungus-seed interaction for subtraction of the incidental and consequent interferences in physiological quality (Araújo et al., 2006; Costa et al., 2003) which, in the present study, were minimal.

The results obtained in assessment of death in preemergence of maize seeds/seedlings (Figure 1) were higher than those of the transmission rates of symptomatic and asymptomatic plants (Figures 2 and 3 ) for all the inoculum potentials. According to Tanaka and Machado (1985), the quantity of inoculum present in the seed influences germination and transmission of pathogens. When associated with the seed, they may cause death in pre- and post-emergence of seedlings, therefore reducing crop stand. 


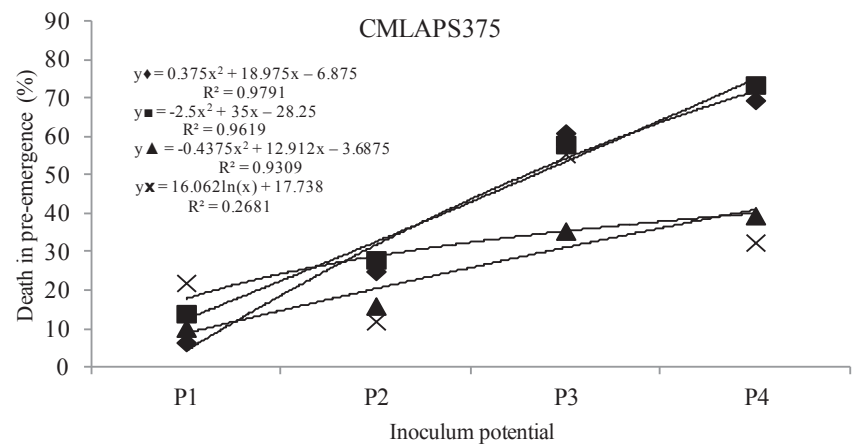

A

$\boldsymbol{\nabla} 20^{\circ} \mathrm{C}-\mathrm{C} 1 \quad 25^{\circ} \mathrm{C}-\mathrm{C} 1 \quad \Delta 20^{\circ} \mathrm{C}-\mathrm{C} 2 \quad \times 25^{\circ} \mathrm{C}-\mathrm{C} 2$

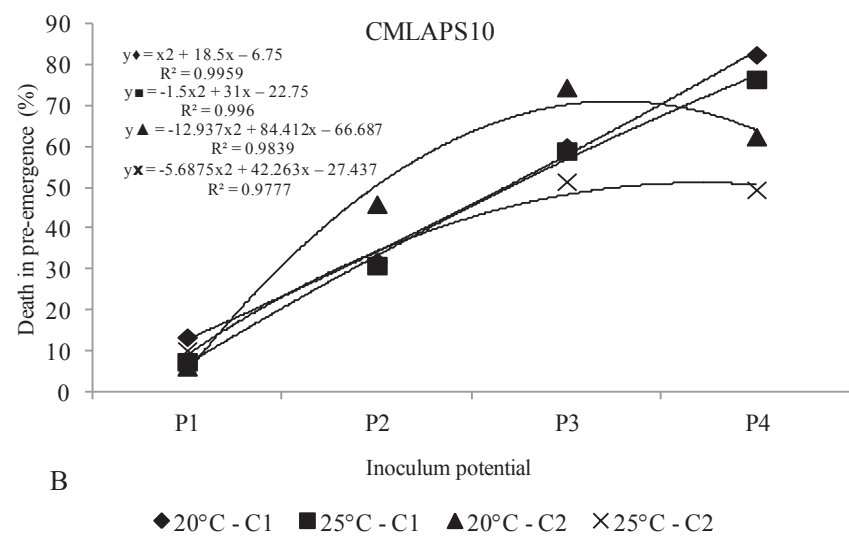

Figure 1. Assessment of the death of seeds/seedlings in preemergence caused by the fungus Stenocarpella macrospora in relation to the isolates CMLAPS375 (A) and CMLAPS10 (B) at the inoculum potentials P1 (24 h), P2 (48 h), P3 (72 h), and P4 (96 h), in the cultivars C1 (RB9308YG) and C2 (RB9108), kept at the temperatures of $20^{\circ} \mathrm{C}$ and $25^{\circ} \mathrm{C}$.

The highest percentages of death in pre-emergence were reached in the P3 and P4 inoculum potentials for both isolates, both temperatures, and both cultivars. In the $\mathrm{P} 3$ and P4 potentials for the CMLAPS375 isolate, the maximum percentages were $61 \%$ and $73.5 \%$, respectively, for the $\mathrm{C} 1$ cultivar, with characteristics of pathogen susceptibility at both growing temperatures, reinforcing the difference of cultivar response to the pathogen (Mendes et al., 2011). However, for the isolate CMLAPS10, the same result was not observed the maximum value for $\mathrm{P} 3$ was $74.5 \%$, occurring for the two cultivars maintained at $20{ }^{\circ} \mathrm{C}$, and, for $\mathrm{P} 4$, the maximum percentage was $82.5 \%$ for $\mathrm{C} 1$, at the two growing temperatures.

These results in reference to death in pre-emergence for maize seeds/seedlings infected by S. macrospora reflected the most recurrent consequence of the activity of this pathogen, compromising germination of maize seeds (Casa et al., 2006). In a study with Colletotrichum gossypii var. cephalosporioides

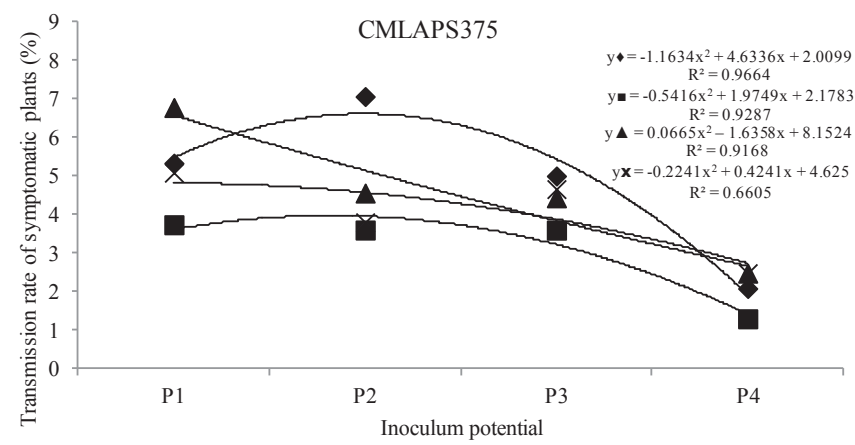

A

• $20^{\circ} \mathrm{C}-\mathrm{C} 1 \quad 25^{\circ} \mathrm{C}-\mathrm{C} 1 \quad \Delta 20^{\circ} \mathrm{C}-\mathrm{C} 2 \quad \times 25^{\circ} \mathrm{C}-\mathrm{C} 2$

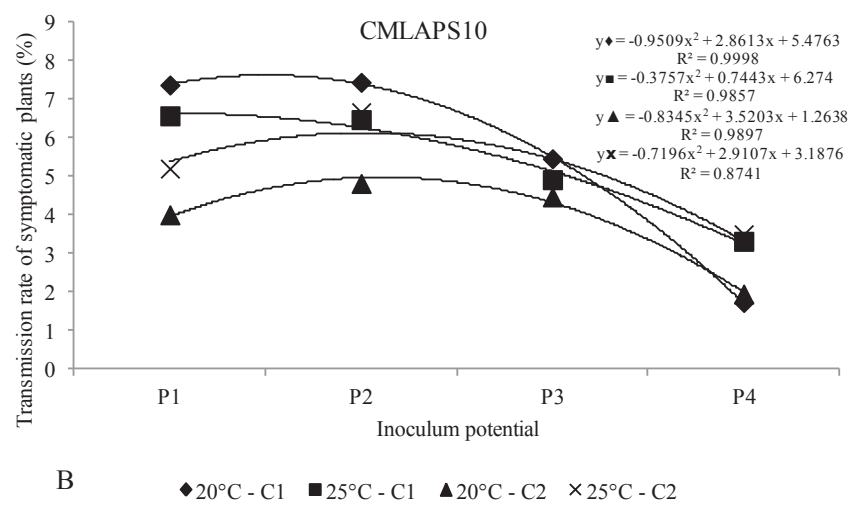

Figure 2. Transmission rates of Stenocarpella macrospora in symptomatic plants for the two isolates (CMLAPS375-A and CMLAPS10-B) at the potentials P1, P2, P3, and P4 (24 h, $48 \mathrm{~h}, 72 \mathrm{~h}$, and $96 \mathrm{~h}$ ), cultivars C1 (RB9308YG) and C2 (RB9108), at the temperatures of $20^{\circ} \mathrm{C}$ and $25^{\circ} \mathrm{C}$.

in cotton seeds, Araújo et al. (2006) also observed that higher temperatures of osmotic conditioning, together with presence of the fungus, led to progressive reduction in seed germination. Another study that corroborates the results obtained in this research was that of common bean seeds inoculated with $F$. oxysporum f. sp. phaseoli, in which a proportional reduction was observed in germination of normal seedlings with a 0 to 144 hour incubation period (Costa et al., 2003).

S. macrospora is a pathogen which most commonly exhibits symptoms over more advanced vegetative stages of the plant, culminating in a high incidence at the end of the crop cycle, which may explain the low transmission rates for symptomatic plants observed in this study (Figure 2). The lesions found in the plants were the same as those described in the literature in the initial phases of the symptomatology of leaf spots, in which lesions were seen in the form of chlorotic tissue, followed by necrosis. The lesions had an irregular 
format, normally measuring from 1 to $3 \mathrm{~cm}$ in length, with a tan color and, at times, exhibiting darker concentric rings as of the initial point of infection. In addition, these first lesions could also be seen in the form of small yellowish or tan streaks that later increased in size, extending in the longitudinal direction of the leaf, which were able to tear the infected plant tissue (Casa et al., 2006; Duarte et al., 2009).

The transmission rates for symptomatic plants (Figure 2) were higher in the P1 and P2 inoculum potentials, for both isolates. It was observed that P1 exhibited the highest stand and P4 the lowest stand compared to the other potentials. Therefore, in $\mathrm{P} 4$, the lowest occurrence of symptoms in surviving plants was seen, and this indicates that death in preand post-emergence is the main consequence of high inoculum potentials of the pathogen. For the isolate CMLAPS375, potentials $\mathrm{P} 1$ and $\mathrm{P} 2$ led to the highest transmission rates for symptomatic plants of $6.8 \%$ and $7.1 \%$, respectively, and, for CMLAPS10, of 7.4\% (P2 and P3). These results occurred in $\mathrm{C} 1$ grown at $20^{\circ} \mathrm{C}$; although in literature the temperature of

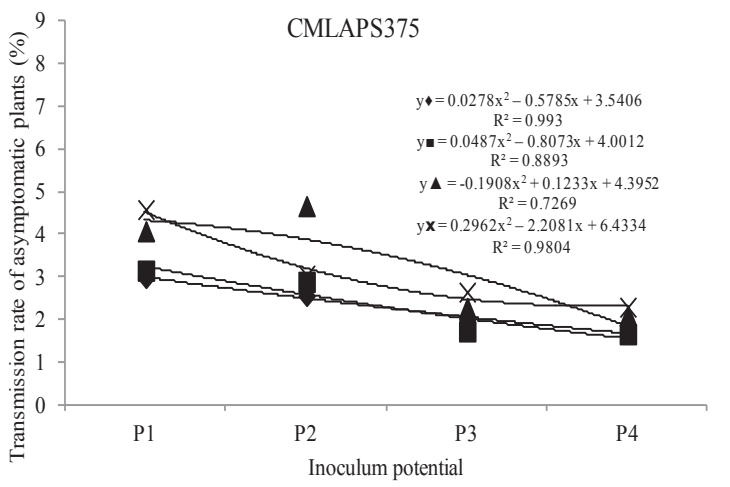

A

- $20^{\circ} \mathrm{C}-\mathrm{C} 1 \quad 25^{\circ} \mathrm{C}-\mathrm{C} 1 \quad \Delta 20^{\circ} \mathrm{C}-\mathrm{C} 2 \quad \times 25^{\circ} \mathrm{C}-\mathrm{C} 2$

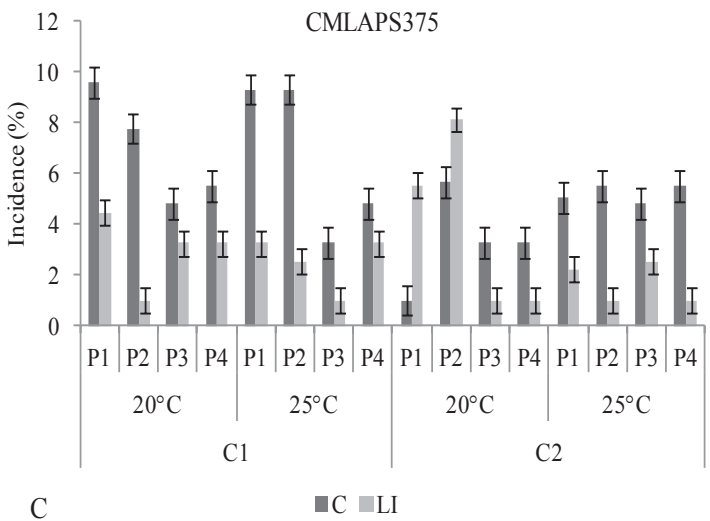

$25^{\circ} \mathrm{C}$ is indicated as one of the most favorable conditions for the activity of $S$. macrospora (Casa et al., 2007).

When compared to the transmission rates for asymptomatic plants, the rates in relation to symptomatic plants were higher, but they generally occurred at potentials $\mathrm{P} 1$ and $\mathrm{P} 2$; for the asymptomatic plants, the highest rates occurred at P1 for the cultivar $\mathrm{C} 1$ kept in temperature of $20^{\circ} \mathrm{C}$.

In the asymptomatic plants (Figures $3 \mathrm{~A}$ and $\mathrm{B}$ ), incidence of the fungus on root collar and last leaf insertion, was observed only in few cases, reflecting the low transmission rates observed in those treatments. The highest percentages occurred at the P1 inoculum potential, in which $6.9 \%$ was observed for $\mathrm{C} 1$ at temperature of $20{ }^{\circ} \mathrm{C}$ with the isolate CMLAPS10; which was the isolate responsible for most of the positive results for latent infection by $S$. macrospora in the plants analyzed. These results were compiled including the positive results provided by the Bio-PCR technique, which allowed detection of $S$. macrospora in almost all the treatments assessed with asymptomatic plants.

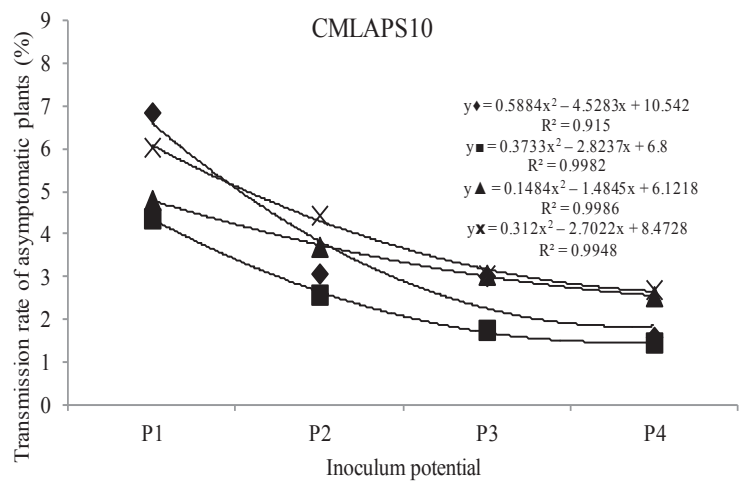

B

- $20^{\circ} \mathrm{C}-\mathrm{Cl} \quad 25^{\circ} \mathrm{C}-\mathrm{C} 1 \quad \Delta 20^{\circ} \mathrm{C}-\mathrm{C} 2 \quad \times 25^{\circ} \mathrm{C}-\mathrm{C} 2$

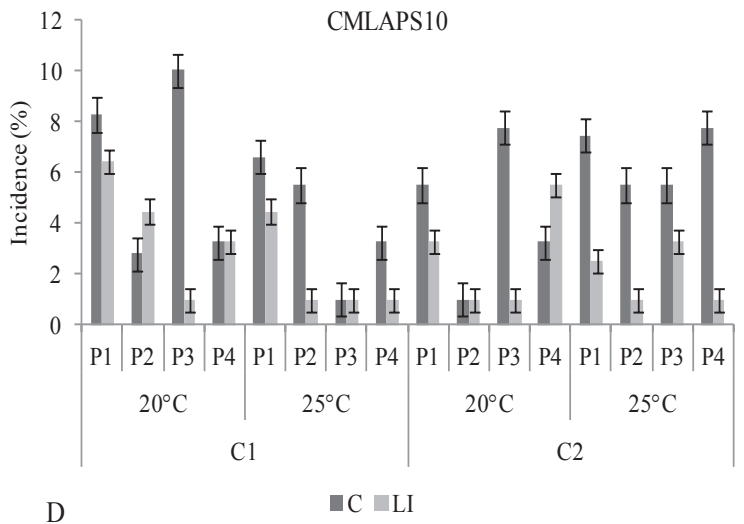

Figure 3. A and B - Transmission rate of Stenocarpella macrospora in asymptomatic plants. C and D - Incidence of $S$. macrospora in the sectioned parts of plants: root collar (C) and the last leaf insertion (LI). C - isolate CMLAPS375 and D - isolate CMLAPS10, at the inoculum potentials P1 (24 h), P2 (48 h), P3 (72 h), and P4 (96 h), in the two cultivars (C1-RB9308YG and C2-RB9108) and two growing temperatures $\left(20^{\circ} \mathrm{C}\right.$ and $\left.25^{\circ} \mathrm{C}\right)$. 
The highest percentage of positive results detected for the pathogen in the Bio-PCR (Figure 4) occurred for the isolate CMLAPS375, with $8.21 \%$ incidence in the $\mathrm{C} 2$ plants kept at $20{ }^{\circ} \mathrm{C}$. For the isolate CMLAPS10, the maximum percentage also occurred in the same cultivar and temperature observed for CMLAPS375; however, the incidence was $7.78 \%$. It is important to register that positive results in PCR analysis for the presence of fungi in asymptomatic plants should be considered with caution because the pathogen may be unviable for developing and causing disease.
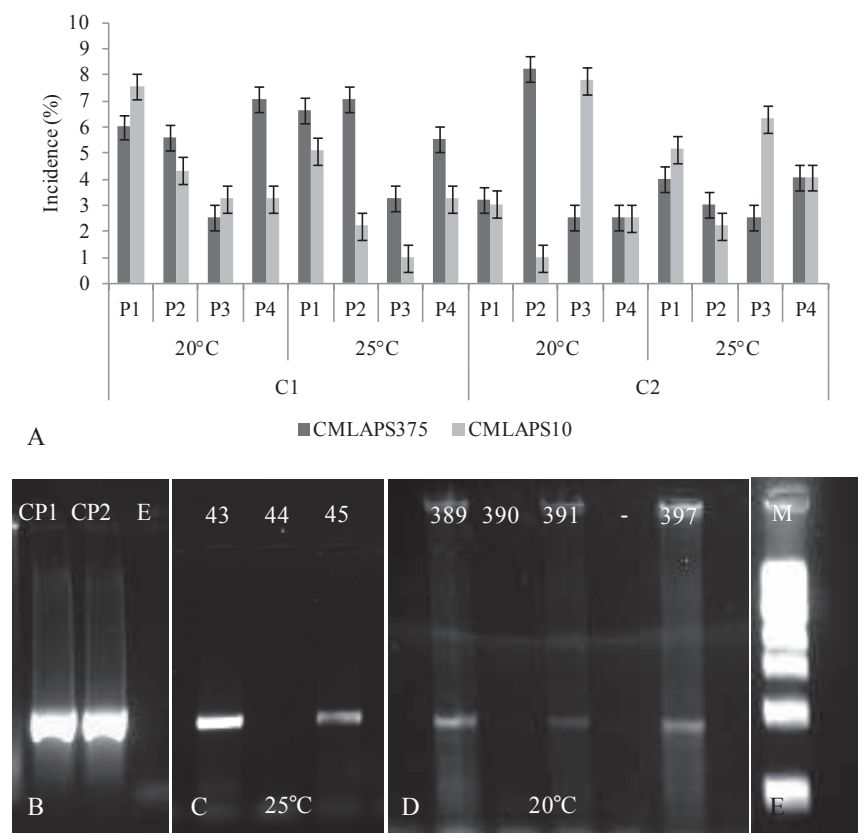

Figure 4. A - Detection of the isolates CMLAPS375 and CMLAPS10 of Stenocarpella macrospora at the inoculum potentials P1-24 h, P2-48 h, P3-72 h, and P4-96 $\mathrm{h}$ by the Bio-PCR technique undertaken in sections of asymptomatic plants of the cultivars C1-RB9308YG and C2-RB9108 developed at the temperatures of $20^{\circ} \mathrm{C}$ and $25^{\circ} \mathrm{C}$. B - positive control of the Bio-PCR (CP1 and CP2) and water (E). C some positive results of plant samples kept at $25^{\circ} \mathrm{C}$ (43 and 45). D - positive results of plant samples kept at $20^{\circ} \mathrm{C}(389,391$, and 397). E - marker.

In relation to the parts of the asymptomatic plants assessed (Figures $3 \mathrm{C}$ and D), root collar (C) and region of the last leaf insertion (LI), it was possible to observe a higher occurrence of the fungus in the root collar region, for both isolates, a maximum of $10.04 \%$ incidence of CMLAPS10 at P3 potential and $9.59 \%$ of CMLAPS375, at P1. With regard the incidence of $S$. macrospora at the last leaf insertion, the maximum percentage was $8.13 \%$ for the isolate CMLAPS375 in P2.
Considering that the asymptomatic plants presented a higher incidence of the pathogen in the region of the root collar, this may be related to the permanence of the fungus in this part of the plant from which the pathogen under favorable conditions may cause the disease collapse. This kind of infection is similar what takes place in the field, where infected plant organs near or below the soil derived from contaminated seeds represent source of inoculum for the disease development (Casa et al., 2006; Reis et al., 2004). From the transmission rates observed in this study, it turns out that the asymptomatic plants will be certainly able to transmit the pathogen from the mother plant to the seeds on the ear.

For S. macrospora transmission of the pathogen was observed (Figure 5), from the seed to the plant, at all the inoculum potentials and it increased from the lower to the higher potentials, i.e., the highest rates of total transmission were reached at $\mathrm{P} 3$ and $\mathrm{P} 4$ for both isolates, both temperatures and both cultivars. At the highest inoculum potential, P4, the highest rates, $76.4 \%$ and $85.8 \%$, occurred for CMLAPS375 and CMLAPS10, both being for C1 (RB9308YG) at the two growing temperatures. For this cultivar, high rates of total transmission were observed in all the treatments, confirming the susceptibility of this genotype. Taking into consideration the lowest rate of total transmission of this pathogen, $15 \%$, which occurred with the isolate CMLAPS10 at potential P1 and cultivar $\mathrm{C} 2$ (RB9108), at the temperature of $20^{\circ} \mathrm{C}$, it was observed that even in the less favorable conditions for the pathogen, this interaction should be considered of great significance from the epidemiological point of view. For both potentials, P2 and P3, the values of total transmission rates were around $50 \%$ for both isolates, both temperatures and both cultivars.

The total transmission rates observed were directly proportional to and progressive with the inoculum potentials, i.e., the longer the period of time the seed remained in contact with $S$. macrospora, the higher infection of seed tissues and, consequently, the higher transmission of the pathogen to the plants from the seed. The same was observed by Botelho et al. (2013) in a study on Sclerotinia sclerotiorum in common bean seeds, in which there was an increase of the disease when the inoculum potential, obtained by the variation of the time of inoculation, increased from 36 to 96 hours of contact of the seeds with the pathogen in two cultivars assessed in the study. Barrocas et al. (2014) also verified this proportionality as a result of increases in the inoculum potentials in cotton seeds inoculated with Colletotrichum gosypii var. cephalosporioides. However, in another study with maize seeds and the fungus Acremonium strictum, Teixeira and Machado (2003) observed that the infection rate, assessed in the above ground part of plants at 28 days of age, was higher with an increase in the time of exposure 
of the seeds to the pathogen (from 0 to 120 hours), but the transmission rates were statistically equals for the times of 24 , 72 and 120 hours, differing only in the zero hour time.

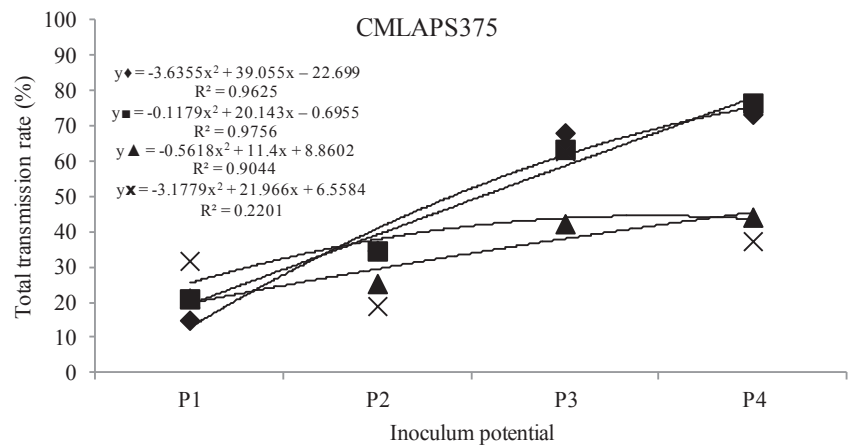

$\mathrm{A} \quad 20^{\circ} \mathrm{C}-\mathrm{C} 1 \square 25^{\circ} \mathrm{C}-\mathrm{C} 1 \quad \Delta 20^{\circ} \mathrm{C}-\mathrm{C} 2 \quad \times 25^{\circ} \mathrm{C}-\mathrm{C} 2$

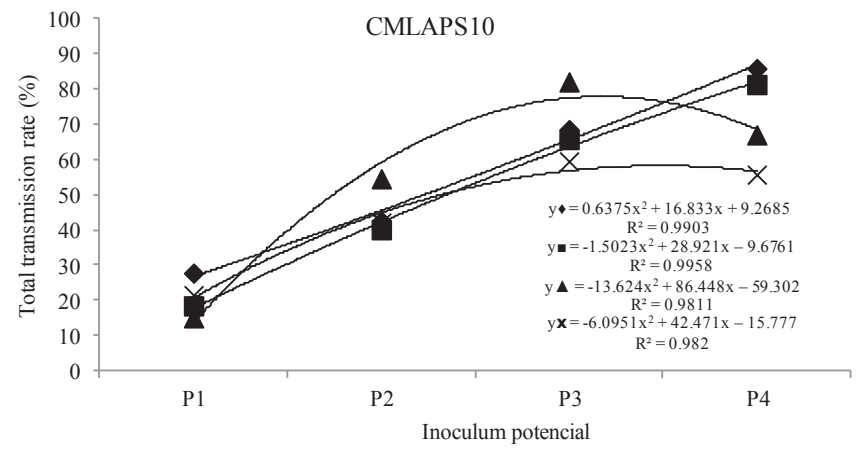

B

- $20^{\circ} \mathrm{C}-\mathrm{C} 1 \quad 25^{\circ} \mathrm{C}-\mathrm{C} 1 \quad \Delta 20^{\circ} \mathrm{C}-\mathrm{C} 2 \quad \times 25^{\circ} \mathrm{C}-\mathrm{C} 2$

Figure 5. Total transmission rate of Stenocarpella macrospora, observing the results of seeds/seedlings with death in pre-emergence, symptomatic plants and asymptomatic plants. A - isolate CMLAPS375 and $\mathrm{B}$ - isolate CMLAPS10, at the inoculum potentials P1 (24 h), P2 (48 h), P3 (72 h), and P4 (96 h), in the cultivars C1 (RB9308YG) and C2 (RB9108), kept at temperatures of $20^{\circ} \mathrm{C}$ and $25^{\circ} \mathrm{C}$.

Once $S$. macrospora comes to the contact with maize seeds and there starts the infection process it may cause high rates of transmission as demonstrated in this study. From the results it was seen that such pathogen may lead to the death of the seed/seedling or generate symptomatic or asymptomatic plants, thus making this association undesirable. This reinforces the importance of the use of healthy seeds, free of this type of infection, which provides support to the certification programs that establish health standards for this type of pathogen under discussion in Brazil.

\section{Conclusions}

Total transmission of $S$. macrospora from maize seeds to plants may reach high rates, maximum of $85.8 \%$.

Transmission of $S$. macrospora by maize seeds may occur in an asymptomatic manner under certain circumstances reaching rate of $6.9 \%$.

Death in pre-emergence and total transmission rates are directly proportional to the inoculum potentials of $S$. macrospora in maize seeds.

\section{Acknowledgments}

To the CNPq, CAPES, and FAPEMIG for financial support to carry out this study.

\section{References}

ARAÚJO, D.V.; POZZA, E.A.; MACHADO, J.C.; ZAMBENEDETTI, E.B.; CELANO, F.A.O.; CARVALHO, E.M.; CAMARGOS, V. N. Influência da temperatura e do tempo de inoculação das sementes de algodão na transmissibilidade de Colletotrichum gossypii var. cephalosporioides. Fitopatologia Brasileira, v.31, n.1, p.035-040, 2006. http://www.scielo.br/ $\mathrm{pdf} / \mathrm{fb} / \mathrm{v} 31 \mathrm{n} 1 / \mathrm{a} 06 \mathrm{v} 31 \mathrm{n} 1 . \mathrm{pdf}$

BRASIL. Ministério da Agricultura, Pecuária e Abastecimento. Regras para análise de sementes. Ministério da Agricultura, Pecuária e Abastecimento. Secretaria de Defesa Agropecuária. Brasília: MAPA/ACS, 2009a. 395p. http:// www.agricultura.gov.br/arq_editor/file/2946_regras_analise_sementes.pdf

BRASIL. Ministério da Agricultura, Pecuária e Abastecimento. Manual de Análise Sanitária de Sementes. Ministério da Agricultura, Pecuária e Abastecimento. Secretaria de Defesa Agropecuária. Brasília: MAPA/ ACS, 2009b. 200p. http://www.agricultura.gov.br/arq editor/file/12261_ sementes_-web.pdf

BARROCAS, E.N.; MACHADO, J.C.; ALVES, M.C.; CORRÊA, C.L. Desempenho de sementes de algodão submetidas à deficiência hídrica e presença de Colletotrichum gossypii var. cephalosporioides. Bioscience Journal, v.30, n.2, p.421-428, 2014. http://www.seer.ufu.br/index.php/ biosciencejournal/article/view/17993

BARROCAS, E.N.; MACHADO, J.C.; ALMEIDA, M.F.; BOTELHO, L.S.; VON PINHO, E.V.R. Sensibility of the PCR technique in the detection of Stenocarpella sp. associated with maize seeds. Revista Brasileira de Sementes, v.34, n.2, p.218-224, 2012. http://www.scielo.br/pdf/rbs/v34n2/05.pdf

BOTELHO, L.S.; ZANCAN, W.L.A.; MACHADO, J.C.; BARROCAS, E.N. Performance of common bean seeds infected by the fungus Sclerotinia sclerotiorum. Journal of Seed Science, v.35, n.2, p.153-160, 2013. http:// www.scielo.br/pdf/jss/v35n2/03.pdf

CASA, R.T.; REIS, E.M.; ZAMBOLIM, L. Decomposição dos restos culturais do milho e sobrevivência saprofítica de Stenocarpella macrospora e S. maydis. Fitopatologia Brasileira, v.28, n.4, p.355-361, 2003. http://www. scielo.br/pdf/fb/v28n4/17007.pdf

CASA, R.T.; REIS, E.M.; ZAMBOLIM, L. Doenças do milho causadas por fungos do gênero Stenocarpella. Fitopatologia Brasileira, v.31, n.5, p.427439, 2006. http://www.scielo.br/pdf/fb/v31n5/01.pdf 
CASA, R.T.; REIS, E.M.; ZAMBOLIM, L.; MOREIRA, E.N. Efeito da temperatura e de regimes de luz no crescimento do micélio, germinação de conídios e esporulação de Stenocarpella macrospora e Stenocarpella maydis. Fitopatologia Brasileira, v.32, p.137-142, 2007. http://www.scielo.br/pdf/fb/ v32n2/07.pdf

COSTA, M.L.N.; MACHADO, J.C.; GUIMARÃES, R.M; POZZA, E.A; ORIDE, D. Inoculação de Fusarium oxysporum f.sp. phaseoli em sementes de feijoeiro através de restrição hídrica. Ciência e Agrotecnologia, v.27, n.5, p.1023-1030, 2003. http://www.scielo.br/pdf/cagro/v27n5/a08v27n5.pdf

DUARTE, R.P.; JULIATTI, F.C.; FREITAS, P.T. Eficácia de diferentes fungicidas na cultura do milho. Bioscience Journal, v.25, n.4, p.101-111, 2009. http://www.seer.ufu.br/index.php/biosciencejournal/article/view/6966/4614

FERREIRA, D.F. SISVAR: A computer statistical analysis system. Ciência e Agrotecnologia, v.35, n.6, p.1039-1042, 2011. http://www.scielo.br/pdf/ cagro/v35n6/a01v35n6.pdf

MACHADO, J.C.; BARROCAS, E.N.; COSTA, M.L.N.; GUIMARÃES, R.M.; MACHADO, C.F. Uso da técnica de restrição hídrica ou condicionamento osmótico em patologia de sementes. Revisão Anual de Patologia de Plantas, v.20, p.1-24, 2012.

MARIO, J.L.; REIS, E.M. Método simples para diferenciar Diplodia macrospora de D. maydis em testes de patologia de sementes de milho. Fitopatologia Brasileira, v.26, n.3, p.670-672, 2001. http://www.scielo.br/ $\mathrm{pdf} / \mathrm{fb} / \mathrm{v} 26 \mathrm{n} 3 / \mathrm{a} 18 \mathrm{v} 26 \mathrm{n} 3 . \mathrm{pdf}$

MARIO, J.L.; REIS, E.M.; JULIATTI, F.C. Three inoculation methods for screening corn germplasm to white ear rot resistance. Tropical Plant Pathology, v.36, n.6, p.362-366, 2011. http://www.scielo.br/pdf/tpp/v36n6/04.pdf

MENDES, M.C.; VON PINHO, R.G.; MACHADO, J.C.; ALBUQUERQUE, C.J.B.; FALQUETE, J.C.F. Qualidade sanitária de grãos de milho com e sem inoculação a campo dos fungos causadores de podridões de espigas. Ciência e Agrotecnologia, v.35, n.5, p.931-939, 2011. http://www.scielo.br/pdf/cagro/ v35n5/a10v35n5.pdf
MICHEL, B.E.; RADCLIFFE, D. A computer program relating solute potential to solution composition for five solutes. Agronomy Journal, v.87, n.1, p.131-136, 1995. http://www.scielo.br/scielo.php?script=sci_ nlinks\&ref=000161\&pid=S2317-1537201300020000300013\&lng=e

PETATÁN-SAGAHÓN, I.; ANDUCHO-REYES, M.A.; SILVA-ROJAS, H.V.; ARANA-CUENCA, A.; TELLEZ-JURADO, A.; CÁRDENAS-ÁLVAREZ, I.O.; MERCADO-FLORES, Y. Isolation of bacteria with antifungal activity against the phytopathogenic fungi Stenocarpella maydis and Stenocarpella macrospora. International Journal of Molecular Sciences, v.12, p.5522-5537, 2011. http://www.ncbi.nlm.nih.gov/pmc/articles/PMC3189730/

REIS, E.M.; CASA, R.T.; BRESOLIN, A.C.R. Manual de diagnose e controle de doenças do milho. Lages: Grapel, 2004.144p.

SILVA, A.R.; JULIATTI, F.C. Esporulação de Diplodia maydis e Diplodia macrospora em diferentes meios de cultura. Bioscience Journal, v.21, n.3, p.127-131, 2005. http://snida.agricultura.gov.br:81/cgibin\%5Cwxis.exe?IsisScript $=$ Cenagri_Search.xis\&method $=$ post $\&$ caminho $=$ f: $|x i t a m i|$ webpages $\backslash$ binagri $\backslash$ bases $\backslash \&$ agb $=$ agb\& formato $=1 \&$ quantidade $=25 \&$ proxdoc $=1$ \&inver$\mathrm{so}=$ on\&expressao $=$ Juliatti, $\% 20 \mathrm{~F}$.C.

TANAKA, M.A.S.; MACHADO, J.C. Patologia de sementes. Informe Agropecuário, v.11, n.122, p.40-46. 1985.

TEIXEIRA, H; MACHADO, J.C. Transmissibilidade e efeito de Acremonium strictum em sementes de milho. Ciência e Agrotecnologia, v.25, n.5, p.10451052, 2003. http://www.scielo.br/pdf/cagro/v27n5/a11v27n5.pdf

XIA, Z.; ACHAR, N. Random amplified polymorphic DNA and polymerase chain reaction markers for the differentiation and detection of Stenocarpella maydis in maize seeds. Journal Phytopathology, v.149, n.1, p.35-44, 2001. http://onlinelibrary.wiley.com/doi/10.1046/j.1439-0434.2001.00572.x/pdf 